\title{
ZNANSTVENA KOMUNIKACIJA U BIOMEDICINI I ZDRAVSTVU
}

\author{
Josip Šimić, Dragan Babić \\ Fakultet zdravstvenih studija, Sveučilište u Mostaru, Bosna i Hercegovina \\ Rad je primljen 26.09.2018. Rad je recenziran 13.10.2018. Rad je prihvaćen
}

Razvoj znanstvene djelatnosti i moderne znanosti je teško odvojiti od razvoja znanstvene komunikacije bilo da se radi o formalnim ili neformalnim mrežama koje koriste znanstvenici. Nastanak novih otkrića u znanosti podrazumijeva i proces komuniciranja u znanosti. Znanstvena komunikacija omogućuje bolju suradnju između znanstvenika, odnosno, omogućuje napredak u znanosti u svim područjima. Objavljena znanstvena informacija predstavlja završnu fazu znanstvenoga rada. S jedne strane znanstvenici prikupljaju prethodna znanja kako bi radili daljnja istraživanja, a s druge strane je potrebno osigurati dostupnost znanstvenih radova ostalim znanstvenicima.

Znanstvena komunikacija predstavlja i svojevrstan sustav kroz koji se znanstveni i stručni radovi kreiraju, evaluiraju radi utvrđivanja kvalitete, diseminiraju i čuvaju za buduću uporabu (1). Formalna komunikacija u znanosti se, osim preko časopisa, odvija još i putem knjiga, ocjenskih radova poput doktorskoga i magistarskoga rada, radnih dokumenata i patenata (2). Neformalna komunikacija u znanosti nastaje najčešće tijekom istraživanja i pisanja znanstvenih radova (neobrađeni podaci kliničkih ispitivanja prije statističke analize, bilješke $u$ laboratoriju, podaci zabilježeni instrumentima i sl.) (3). Tako je uobičajena komunikacija između kolega unutar neke obrazovne institucije, između kolega na sastancima, ali i komunikacija sa kolegama izvan ustanove. Zahvaljujući sve većim mogućnostima digitalne tehnologije sve veća je mogućnost razmjene istraživačkih podataka kliničkih istraživanja čime bi se ubrzalo stvaranje znanja, povećala pouzdanost dokaza i tako doprinijela integritetu istraživanja (4).

Znanstvena komunikacija se uglavnom odvija kroz znanstvene publikacije poput članaka u časopisima. Znanstvena informacija koja se objavljuje u znanstvenom članku treba biti nova na razini cijeloga čovječanstva te članak za nju treba uputiti na jasne dokaze (5). Uloga časopisa postaje sve važnija kako se znanost počela razvijati i granati u više područja koji su bili sve slabije povezani. Prvi znanstveni časopisi su počeli izlaziti još 1665 . godine te se zajedno sa razvojem znanosti do današnjega dana pokazao vrlo uspješnim (6). Njegova uloga je važna i kako bi znanstvenici podijelili svoje znanstvene ideje i spoznaje svojim kolegama i pojedincima (7). Tako znanstveni časopisi, podržani sustavima koji podupiru znanstvenu komunikaciju, utječu na više aspekata razvoja znanosti i znanstvenika. Važni su za zaštitu intelektualnog vlasništva, omogućavanje dijeljenja ideja i spoznaja, preko časopisa se omogućuje mjerenje kvalitete rada nekog znanstvenika, samim time veliki je utjecaj i na njihovo napredovanje.

Sustavi koji podupiru znanstvenu komunikaciju su: Sustavi za pretraživanje znanstvenih informacija; Sustavi provjere radova; Sustavi za identifikaciju u znanstvenoj komunikaciji; Sustavi citiranja.

Sustavi za pretraživanje znanstvenih informacija podrazumijevaju sve akademske baze podataka koje sadrže znanstvene informacije koje se mogu pojavljivati u nekoliko oblika. Postoji više baza podataka koje se koriste prilikom pretraživanja u području biomedicine i zdravstva. One se uglavnom dijele na citatne i bibliografske baze. Najpoznatije citatne baze su Web of Science i Scopus dok je najpoznatija bibliografska baza u području biomedicinskih znanosti Medline.

Baza Web of Science (WoS) sadrži nekoliko citatnih indeksa poput Science Citation Index Expanded (SCI-EXP), Social Science Citation Index (SSCI) i Art \&HumanitiesCitation Index (A\&HCI). U 
okviru navedene baze 2015. godine je predstavljen novi citatni indeks znanstvenih časopisa pod nazivom Emerging Sources Citation Index (ESCI) (8). Časopisi koji se nalaze u ovom citatnom indeksu su vidljivi u bazi WoS, ali se za njih ne izračunava faktor odjeka i predstavlja neku vrstu čekaonice za indeksiranje u SCI-EXP, SSCI i A\&HCI.

Scopus je najveća interdisciplinarna citatna baza podataka. Unutar baze je indeksiran veliki broj časopisa iz manje razvijenih regija i država (9). U posljednjem desetljeću veliki broj naših i regionalnih časopisa prihvaćeni su u navedenim bazama podataka (10).

Sustavi provjere radova ili sustav recenzije je sustav u kojem sudjeluju autori, recenzenti i urednici. Stručnjaci koji provjeravaju znanstvene radove odnosno provode recenziju imaju obvezu utvrditi razinu kvalitete prije objavljivanja u znanstvenom časopisu. Postoji više načina recenzijskog postupka poput klasične recenzije, kaskadne recenzije te dvostupanjskercenzije (6). Urednici časopisa imaju također važnu ulogu u sustavu provjere kvalitete radova kroz suradnju sa recenzentima, autorima i nakladnicima. Urednici recenzentima daju jasne smjernice i upute za rad uspostavljajući jasne i obvezujuće standarde sukladno profilu časpisu, području koje pokriva i usvojenoj politici uredništva (5).

Sustavi za identifikaciju u znanstvenoj komunikaciju omogućavaju lakše pretraživanje i korištenje znanstvene građe, te pomažu identificiranju znanstvenika koji tu građu proizvode.

Za razne tipove građe koriste se različiti identifikatori poput ISBN (International Standard BookNumber $=$ Međunarodni standardni knjižni broj), ISSN (International Standard SerialNumber), DOI (Digital ObjectIdentifier) - identifikator digitalnog objekta za članke $\mathrm{u}$ časopisima i druge digitalne sadržaje. Za identifikaciju autora koriste se ORCID (Open ResearcherఓContributor ID) i ISNI (International Standard Name Identifier).

Sustavi citiranja podrazumijevaju pravila navođenja izvora tuđeg znanstvenog ili stručnog teksta i vrlo je važan za znanstvenu komunikaciju kako bi obavijestili čitatelja o izvorima kojima se je služio autor. Postoji više sustava i stilova citiranja. Najviše upotrebljavan stil citiranja u području biomedicine i zdravstva je Vancouverski stil. Redni broj reference koji se upotrebljava u tekstu određuje se prema redoslijedu pojavljivanja u autorovu tekstu. Podaci o korištenim izvorima navode se samo u popisu literature (2). Za upravljanje informacijskim izvorima danas koristimo programe za upravljanje referencijama. Postoji nekoliko programa za upravljanje referencijama koje su ušle u svakodnevnu upotrebu poput EndNote (11), Zotero (12), Mendeley (13), RefWorks (14) i dr.

U zaključnom dijelu ovoga rada ističemo i činjenicu kako je za funkcioniranje cjelokupnog procesa znanstvene komunikacije potrebno da studenti, istraživači i znanstvenici posjeduju vještine i znanja kako upotrijebiti znanstvenu informaciju koja je osnovni instrument istraživačkih procesa i znanstvene produkcije (15). Drugim riječima znanstvena komunikacija, osim ovisnosti o navedenim sustavima, ovisi i poznavanju osnovnih sadržaja informacijske pismenosti. Teško je zamisliti sustavnu strategiju podizanja znanstvene produktivnosti na nekom sveučilištu ili u nekoj državi bez edukacije o načinima pronalaženja, vrednovanja i korištenja informacija. Naglašavamo pri tome kako su pojmovi informacijske pismenosti i informatičke pismenosti različiti. Informatička pismenost podrazumijeva znanja o upotrebi računala i računalnih programa. Posjedovanje ove vrste pismenosti ne podrazumijeva i znanja o prepoznavanju potrebe za informacijom, strategijama pretraživanja, vrednovanja i korištenja informacija te znanja o procesu objavljivanja znanstvenih radova (16). U zemljama znanstvene periferije, a Bosna i Hercegovina to jest, posjedovanje informatičke pismenosti često se uzima kao dostatan temelj vještina za sudjelovanje u znanstvenoistraživačkom radu. Takvim pristupom usporavamo razvoj i podizanje znanstvene produktivnosti koja je temeljni pokazatelj kvalitete znanstvenoistraživačkoga rada nekog sveučilišta. Smatramo kako bi se uvođenjem sadržaja informacijskog opismenjavanja u nastavu na visokoškolskim ustanovama $(17,18)$ ), kratkoročnom edukacijom o planiranju istraživanja i pisanju znanstvenih radova u okviru cjeloživotnog učenja znanstvenika iz područja biomedicine (19) i 
zdravstva te jačim uključivanjem knjižnica u cijeli proces $(17,18)$, doprinijelo kvalitetnijoj znanstvenoj komunikaciji kao procesu koji je ključan u razvoju svih područja znanosti, a posebice biomedicinskih i zdravstvenih područja.

\section{LITERATURA}

1. Kurelović-Krelja, E. Prihvaćanje otvorenog pristupa znanstvenim informacijama i obrazovnim sadržajima u Hrvatskoj akademskoj zajednici, Doktorski rad, Zagreb, 2017. str. 18.

2. Petrak, J. Narav i ustrojstvo sustava medicinskih informacija. U: Marušić M, urednik. Uvod u znanstveni rad u medicini, Zagreb: Medicinska naklada, 2013.

3. Mahmić-Kaknjo M, Šimić J, Krleža-Jerić K. Setting the IMPACT (IMProve Access to ClinicalTrial data) Observatory baseline. Biochem Med (Zagreb). 2018;28(1)

4. Krleža-Jerić, K., Gabelica $\mathrm{M}$, Banzi $\mathrm{R}, \mathrm{Kr}$ nić-Martinić M, Pulido B, Mahmić-Kaknjo M, Reverie L, Šimić J, Utrobičić A, Hrgović I. (2016) IMPACT Observatory: tracking the evolution of clinical trial data sharing and research integrity

5. Marušić $\mathrm{M}$, urednik. Uvod u znanstveni rad u medicini, Zagreb: Medicinska naklada, 2013.

6. Hebrang Grgić, Ivana; Časopis i znanstvena komunikacija, Naklada Ljevak, Zagreb. 2016.

7. Vrana, R. Vrednovanje znanstvenog rada. Vjesnik bibliotekara Hrvatske, 2011; 54: 174.

8. www.clarivate.com. Dostupno na: https://clarivate.com/essays/journal-selection-process/ (17.06.2018)

9. www.elsevier.com. Dostupno na: https://www. elsevier.com/solutions/scopus (27.09.2018).

10. Utrobičić, A., Šimić, J., Malički, Marušić A, Marušić M., (2014), Composition of editorial bords and peer review policies of Croatian journals indexed in Web of Science and Scopus. Eur Sci Ed, 40(2) str. 31-3.

11.www.endnote.com. Dostupan na: http://endnote.com/(11.08.2018)

12. www.zotero.org. Dostupan na: https://www.zotero.org/(11.08.2018) 13.www.mendeley.com. Dostupan na: https://www. mendeley.com/(11.08.2018)

14.www.refworks.com. Dostupan na: https://www. refworks.com/(11.08.2018)

15. Špiranec, Sonja. Informacijska pismenost kao oslonac znanstvene komunikacije : argumentacijski i primijenjeni okvir, Hrvatski znanstveni časopisi : iskustva, gledišta, mogućnosti / uredila Ivana Hebrang Grgid. Zagreb : Školska knjiga, 2015. Str. 149.

16.Špiranec, S, Banek, Zorica M. Informacijska pismenost: teorijski okvir i polazišta. Zagreb: Zavod za informacijske studije, 2008.

17. Marušic, A, Marušic, M. Teaching students how to read and write science: a mandatory course on scientific research and communication in medicine. Academic Medicine. 2003;78(12):12351239.

18. D Hren, IK Lukić, A Marušić, I Vodopivec, A Vujaklija, M Hrabak Teaching research methodology in medical schools: students' attitudes towards and knowledge about science. Medical education 2004;38(1):81-86.

19. Mišak A. Marušić, M, Marušić, A. Manuscript editing as a way of teaching academic writing: Experience from a small scientific journal Journal of Second Language Writing 2005;14(2):122131.

20.Davis-Kahl, S, and Hensley, MK.Common Ground of the Nexus of Information Literacy and Scholarly Communication. Association of College\& Research Libraries, Chicago, 2013. Dostupno na: (http://digitalcommons.iwu.edu/bookshelf/36) (21.07.2018)

21. Association of Collegeand Research Libraries. Working Group on Intersections of Scholarly Communication and Information Literacy. Intersections of Scholarly Communication and Information Literacy: Creating Strategic Collaborations for a Changing Academic Environment. Chicago, IL: Association of Collegeand Research Libraries, 2013. 